\title{
IMPORTANCE OF INTELLECTUAL CAPITAL COMPONENTS IN MANAGEMENT DECISION-MAKING PROCESSES OF FRENCH COMPANIES:AN EMPIRICAL STUDY USING SHAPLEY'S VALUE AND LAMBDA FUZZY MEASUREMENT METHOD
}

\author{
Endre Pap ${ }^{1}$, \\ Miloš Petkovićn ${ }^{*}$, \\ Ana Blagojević ${ }^{1}$, \\ Snežana Stanišić2 \\ ${ }^{1}$ Singidunum University, \\ Belgrade, Serbia \\ ${ }^{2}$ Sinergija University, Bijeljina, \\ Republic of Srpska
}

\begin{abstract}
:
Objective: Most of the research work related to the topic of intellectual capital has been focused on the interaction between intellectual capital or its particular components on the different financial performance. This paper contributes to the literature by proposing different levels of contribution of intellectual capital components in the total intellectual capital.

Methodology: This paper adopted quantitative statistical methods Lambda phase measurement and Shapley's value on the sample of 498 French companies in the period of 2008 to 2016 in order to estimate the highest and lowest importance of intellectual capital components.

Findings: By the Shapley's value final result, the greatest importance has the third variable, which represents company's commercial activities. The third variable belongs to the third intellectual capital component - relational capital, and it contributes with the highest coefficient of 0.29911. By the same methods, the Research Asset Value variable has the lowest importance and it represents the value coming from research and development expenses with the coefficient of 0.07463 .

Implications and limitations: Even though, the correlation between intellectual capital components exists as well as their contribution on the final result, the present study points out on different levels of contribution of each intellectual capital component. The limitations of this paper are concentrated on unavailability of the quantitative data from the official annual reports of companies.

Original feature: This study presents the distribution of contribution of different intellectual capital components based on the empirical approach using quantitative data from company's annual reports.
\end{abstract}

\author{
Keywords: \\ Intellectual, Capital, Management, Decision-Making, Companies
}

JEL classification: M10, M41, C60

\section{INTRODUCTION}

Knowledge and intellect are highly difficult to measure and quantify but they will without a doubt influence a company's productivity, efficiency or total profitability. The limits in the valuation process are no longer focused on the production of physical products or providing services. Instead, they are focused on the creation of intellectual capital (Chen, Cheng, and Hwang, 2005). Intellectual capital plays an important role in a company's final success (Pulic 1998; Ordóñez de Pablos 2003; El-Bannany 2008). Intellectual capital can create value for a company and increase investors' confidence (Chen, Cheng, and Hwang, 2005).

Intellectual capital as a strategic resource of each company is not a sole thing; it is composed of many interrelated elements that have been continuously cooperated

Correspondence:

Miloš Petković

e-mail:

mpetkovic@singidunum.ac.rs and supported together as a whole (Bukh et al., 2001). The competitive advantage of a company lies in the complexity of these types of intellectual capital. Success of a company depends on the strategic management of the selected components of intellectual capital (Bayburina and Golovko, 2009). 
Based on the available literature, intellectual capital is classified into three components: human capital, structural capital and relational capital (Roos and Roos, 1997; Saintonge, 1999; Stewart, 1995; Sveiby, 1997; Edvinsson and Stenfelt, 1999; Martínez-Torres, 2006; Subramaniam and Youndt, 2005).

Garanina and Pavlova (2011) prove that a positive interaction between human capital, structural capital and relational capital exists. The interaction between three main components of intellectual capital, human capital, structural capital and relational capital generates benefits to a company (Hermans and Kauranen, 2005; Bayburina and Golovko, 2009).

In an effort to emphasize importance of particular intellectual capital component compared to other two, the purpose of this study is to turn attention on the unique contribution of a component of a total intellectual capital surplus generated by the coalition of all intellectual capital components. A coalition between intellectual capital components gain certain overall gains from that cooperation. Since some components may contribute more to the coalition than others, what final performance should arise in any particular contribution? The question that arises is how important each intellectual capital component is to the overall cooperation within the total intellectual capital value.

Our paper contributes to the literature by proposing the intellectual capital component in which French companies invest the most, taking into consideration their existing interrelations. In that way, a company will pay attention and invest more in particular component in order to gain higher benefits in the upcoming future periods.

The analysis is composed of 498 French companies over the period of 2008 to 2016 . In this paper, the following statistical quantitative methods are implemented: Lambda Phase Measurement Method and Shapley's Value Method.

This paper has four sections. We start with an explanation of intellectual capital components explored in the literature. In the second section, we explain the methodology used to present our research question. The third section is related to our main findings and results, and the last one is about discussing those findings.

\section{LITERATURE REVIEW}

In the knowledge-based economy, it is not enough just to take the traditional and financial measures of a company into account, but it is important to find a way to recognize intellectual capital as well. Traditional measures are highly unsuitable mainly because they are based on conventional accounting principles (Gan, 2008). Knowledge and intellect are highly difficult to measure and quantify but they will without a doubt influence a company's productivity, efficiency or total profitability. The limits in the valuation process are no longer focused on the production of physical products or providing services. Instead, they are focused on the creation of intellectual capital (Chen, Cheng, and Hwang, 2005a).

The concept of intellectual capital was revealed for the first time in 1969 by Kenneth Galbraith. Kenneth Galbraith wrote a letter to the economist, Michael Kalecki, where he stated that "I wonder if you realize how much those of us the world around have owed to the intellectual capital you have provided over these past decades" (Hudson, 1993). Stewart (2001) claimed that the first use of the term 'intellectual capital' dates back to 1959, when he started his study with Itami, who later published the book: "Mobilizing Invisible Assets" in Japan in 1980 (look at newer edition Itami and Roehl, (2009)).

Intellectual capital has been interesting since the Fortune magazine's article of Stewart (1991). Twentieth century is a century of ideas, knowledge, innovations, information and changes. Industries that provide services expanded radically. Simultaneously, the financial market became influential in the global market, so "intellectual capital" obtained a very important role for itself. Market value of a company is composed of total book value, everything that is a company's property and intellectual capital (Pike et al., 2002). Cifuentes (2002) thinks that the adjective "intellectual" eliminates the monetary component of capital, focusing much more on the intelligence in the process of producing products and services.

In the last several years, numerous intensive discussions about intellectual capital and its importance have been initiated. Intellectual capital is seen as a crucial factor for organizational survival and existence in the current global business environment. Because of that, more and more companies present it in the annual reports. In order to develop it internally, companies must possess developed capacities among their employees, organizational departments and levels, stakeholders and top management (Gogan and Draghici, 2013).

According to a synthesis from extant literature, intellectual capital is classified into three components (Bassi and Laurie,1997; Cascio, 1998; Edvinsson and Stenfelt, 1999; Edvinsson and Sullivan, 1996; Marr and Moustaghfir, 2005; Martínez-Torres, 2006; Bontis, 1996; Roos and Roos, 1997; Saintonge, 1999; Stewart, 1995; Subramaniam and Youndt, 2005; Sveiby, 1997):

1) Human Capital - Human capital represents employees' knowledge, competencies and education;

2) Customer Capital - Customer capital represents all relations with customers, suppliers, distributors and other stakeholders. Customer capital is a very important type of intellectual capital for every company mainly because a company is not an isolated entity. It is an organization that continuously interacts with its business environment. 
Business environment, together with its customers and clients, represent a source of knowledge regarding advantages or disadvantages of a company's products or services, new ideas, organizational practices, etc.;

3) Structural Capital - Structural capital refers to organizational systems, culture, practices, processes and business routines (Marr and Moustaghfir, 2005). Structural capital is an organizational structure value of a company and knowledge that is stored in manuals, products concepts, information systems and organizational value (Chatzkel, 2002).

Youndt et al. (2004) state that all intellectual capital components should be treated at once and all together because forgetting one of them will result in losing sight of the whole, intellectual capital. Bayburina and Golovko (2009) and Hermans and Kauranen (2005) prove that interaction between intellectual capital components can lead to the value creation process within a company. Ognjanovic (2017) proved a strong and positive relationship between the observed intellectual capital components based on the combined factor, and analysis and structural equation study of 44 hotel companies in Serbia. The strongest relationship is observed between relational capital and structural capital. Factor analysis confirmed grouping of the defined criteria around these three intellectual capital components. Analyzing the relationship between intellectual capital components, Bontis (1998) proved a medium correlation between human capital, structural capital and relational capital. The same study proved a small correlation only between human capital and relational capital. Bontis et al. (2000) examined the relationship between intellectual capital components of manufacturing and services companies. They confirmed a significant, strong and positive relationship between human capital and structural capital, and between structural capital and relational capital of the observed sample of Malaysian companies. It is also confirmed that there is a positive, but not a significant relationship between human capital and relational capital. Chen et al. (2004) proved a positive and significantly strong relationship between intellectual capital components.

\section{RESEARCH METHODOLOGY AND FINDINGS}

\section{Lambda fuzzy measure and Shapley value}

As an efficient tool for measuring the interaction between elements, fuzzy measure is defined in the following way:

Definition: Let $X=\left\{x_{1}, x_{2}, \ldots, x_{n}\right\}$ be a fixed set. $P(X)$ is a set of all the subsets of the set X. Fuzzy measure on $\mathrm{X}$ is a set function $\mu: P(X) \rightarrow[0,1]$, which meets the following conditions: (i) $\mu(\varnothing)=0, \mu(X)=1$,

(ï) If $A, B \in P(X)$ and $A \subseteq B$, then $\mu(A) \leq \mu(B)$.

In order to determine such a fuzzy measure, we must find total $2^{n}-2$ numbers by which the measure is evaluated, because, according to the above stated value definition, $\mu(\varnothing)$ and $\mu(X)$ are always equal to zero i.e. one. It is obvious that such an evaluation process is rather complex. In order to reduce the complexity of the calculation, $\lambda$-fuzzy measure $g$, which acts as a special kind of fuzzy measure, has been proposed (Sugeno, 1974; Cherubini, 1997; Pap and Blagojević, 2019).

Definition: Let $X=\left\{x_{1}, x_{2}, \ldots, x_{n}\right\}$ be a fixed set. Fuzzy measure $g$ on $\mathrm{X}$ is called $\lambda$-fuzzy measure if the following conditions are met:

$$
g(A \bigcup B)=g(A)+g(B)+\lambda g(A) g(B),
$$

where $\lambda \in(-1, \infty)$ for $\forall A, B \in P(X)$ and $A \cap B=\varnothing$.

Theorem 1. If $\mathrm{X}$ is a final set $\bigcup_{i=1}^{n} x_{i}=X$, the following equation for $\lambda$-fuzzy measure $g$ is given by:

$$
\begin{aligned}
& g\left(\bigcup_{i=1}^{n} x_{i}\right)= \\
& =\left\{\begin{array}{lr}
\frac{1}{\lambda}\left(\prod_{i=1}^{n}\left[1+\lambda g\left(x_{i}\right)\right]-1\right), & \text { za } \lambda \neq 0 \\
\sum_{i=1}^{n} g\left(x_{i}\right), & \text { za } \lambda=0
\end{array}\right\}
\end{aligned}
$$

where $x_{i} \cap x_{j}=\varnothing$, for each $i, j=1, \ldots, n$ and $i \neq j$.

The following is true for each specific subset $A \in P(X)$ :

$$
g(A)=\left\{\begin{array}{ll}
\frac{1}{\lambda}\left(\prod_{i \in A}[1+\lambda g(i)]-1\right), & \text { za } \lambda \neq 0 \\
\sum_{i \in A} g(i), & \text { za } \lambda=0
\end{array}\right\}
$$

Value $\lambda$ can simply be determined by applying the above equation. The equation for $g(X)=1$ is as follows: 


$$
\lambda+1=\prod_{i=1}^{n}\left(1+\lambda g_{i}\right)
$$

Theorem 2.

1) $\quad \lambda>0$ when $\sum_{i=1}^{n} g\left(\left\{x_{i}\right\}\right)<g(X)$,

2) $\lambda=0$ when $\sum_{i=1}^{n} g\left(\left\{x_{i}\right\}\right)=g(X)$,

3) $-\frac{1}{g(X)}<\lambda<0$ when $\sum_{i=1}^{n} g\left(\left\{x_{i}\right\}\right)>g(X)$.

Based on the axiom set, Shapley proposed the definition of a coefficient of importance which is called Shapley value $\varphi_{i}(\mu, X)$ (abbreviated to $\left.\varphi_{i}(\mu)\right)$, and he defined it in the following way:

$$
\begin{aligned}
& \varphi_{i}(\mu, X)= \\
& =\sum_{T \subseteq X \mid\{i\}} \frac{(n-t-1) ! t !}{n !}[\mu(T \cup i)-\mu(T)]
\end{aligned}
$$

where $n, t$ stand for cardinality of set $X$ - and $T$ order.

The Shapley value of a particular variable intuitively represents the average change in prediction that occurs in a coalition when joined by a given variable. Based on the previous equation, we know that Shapley value is an expected value of the total marginal contribution between elements $i$ and any other coalition $T \subseteq X \mid\{i\}$. Having in mind the definition of fuzzy measure, it is easy

to notice that $\varphi_{i}(\mu) \geq 0$ and $\sum_{i=1}^{n} \varphi_{i}(\mu)=1$ for each $i$, which means that $\left\{\varphi_{i}(\mu)\right\}_{i \in X}$, is a weight vector, named Shapley value. When measure $\mu$ is additive, then $\varphi_{i}(\mu)=\mu(i)$, which shows that there is no interaction between elements $i$ and any other coalition $T \subseteq X \mid\{i\}$. In this case, Shapley value becomes a traditional weight vector $\omega=\left(\omega_{1}, \omega_{2}, \ldots, \omega_{n}\right)^{T}$, where $\omega_{i}=\mu(i)$.

When $\mu$ is not additive, if $\varphi_{i}(\mu)>\mu(i)$, then there is a complementary interaction between elements $i$ and any other coalition $T \subseteq X \mid\{i\}$. If $\varphi_{i}(\mu)<\mu(i)$, then there is a redundant interaction between elements $i$ and any other coalition $T \subseteq X \mid\{i\}$. Therefore, Shapley's weight not only offers measure of criteria value, but also maintains their interactive characteristics.
The following example demonstrates the determination of the parameter $\lambda$ and fuzzy measure. The following data are presented in the table: value of the research asset, research and development expenditures, commercial expenses and sales expenses. They are compared in this paper by calculating Shapley values for all four variables. 


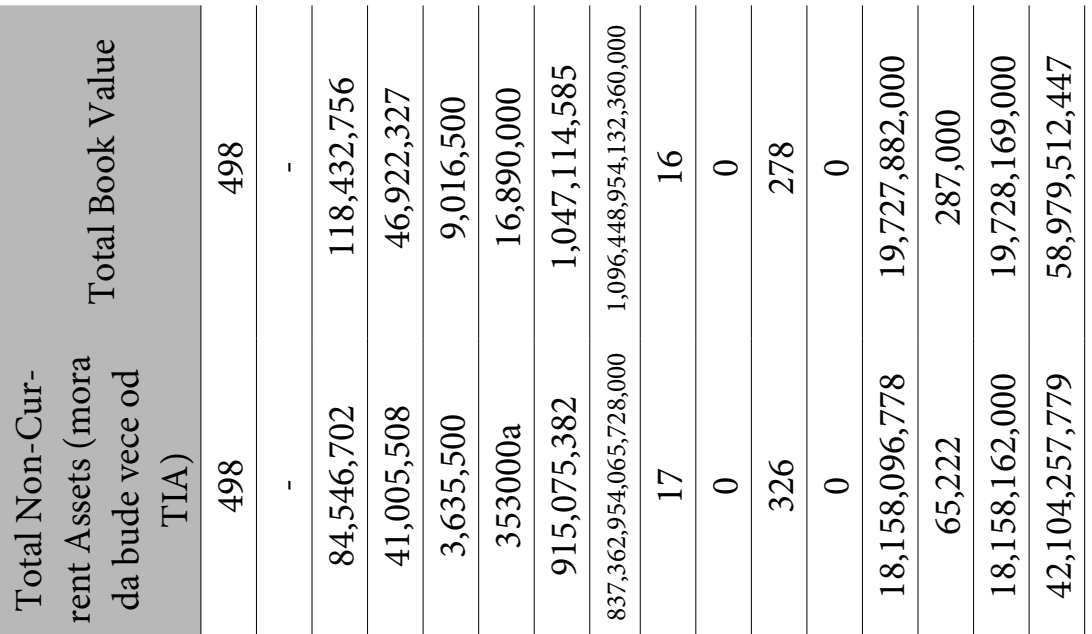

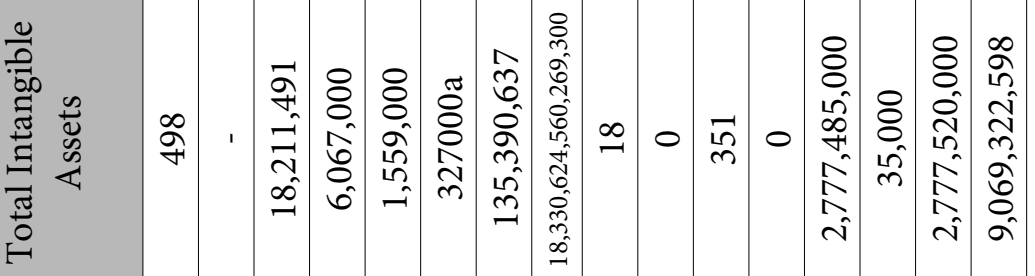

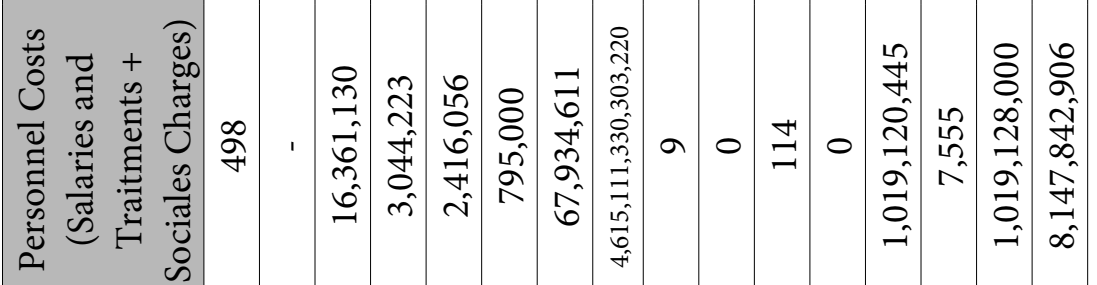

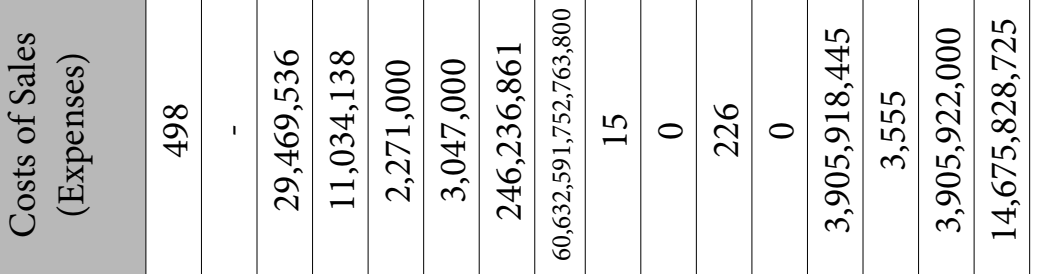

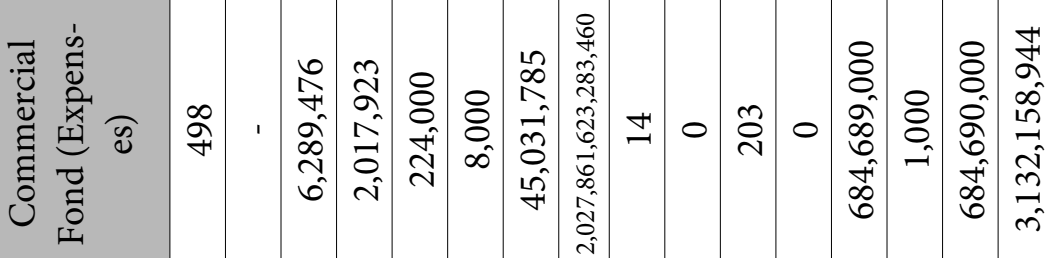

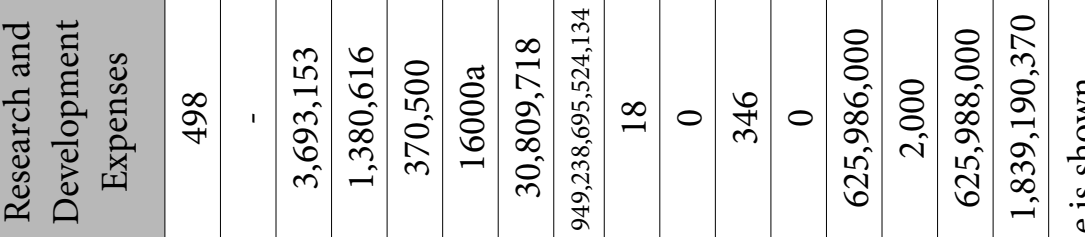

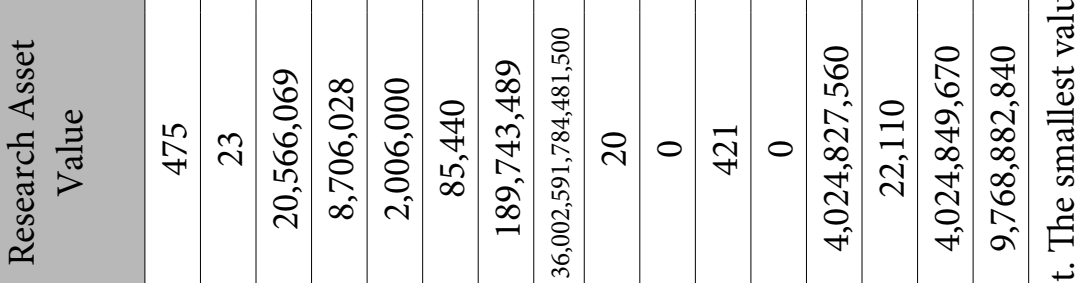

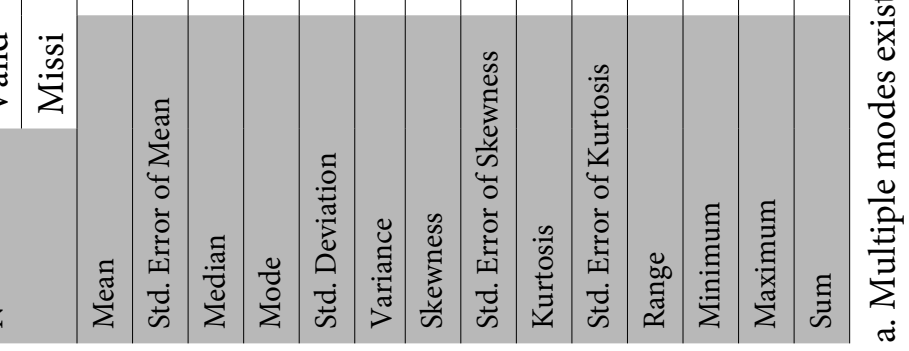


For the purpose of calculating it more easily, the set of variables in the table is marked as $\mathrm{X}$, and each variable is allocated a letter in the following order a, b, c,

d. $X=\{a, b, c, d\}, \mu(X)=1, \mu(\{a\})=0.2037$

" $\mu(\{b\})=0.3693, \mu(\{c\})=0.6289$, $\mu(\{d\})=0.2947$. We then use the formula (3) to calculate the parameter $\lambda$. Since $\sum_{i=1}^{6} \mu\left(\left\{x_{i}\right\}\right)>\mu(X)$ and based on the Theorem 2 , we expect $-1<\lambda<0$ to be true. We get the following equation:

$(1+\lambda \cdot 0,2037) \cdot(1+\lambda \cdot 0,3693) \cdot(1+\lambda \cdot 0,6289) \cdot(1+\lambda \cdot 0,2947)=\lambda+1$.

which is transformed into an equation of fourth degree:

$\lambda^{4} \cdot 0.0139+\lambda^{3} \cdot 0.1756+\lambda^{2} \cdot 0.7897+\lambda \cdot 0.4966=0$
Using the halving method, we obtain an approximate solution of the previous equation where the mistake is lower than $10^{-2}$. The number of steps is determined by the following condition:

$$
\frac{B-A}{2^{n}} \leq 10^{-2} \Leftrightarrow n \geq 7
$$

Applying the halving method, we obtain a series of approximations by finding the midpoint of the interval:

$$
x_{1}=\frac{A+B}{2}=\frac{-1+0}{2}=-0.5
$$

And then, using a function sign $\left(f\left(x_{1}\right)>0\right)$ we check which half of the interval has a root of the equation. The same method is repeated on that half of the interval with the new $A$ and $\mathrm{B}$. We search for the midpoint of the interval again and we repeat the method 7 times. All the values are given in the table:

\begin{tabular}{ccccc}
\hline $\mathrm{n}$ & $\mathrm{A}$ & $\mathrm{B}$ & $\mathrm{xn}$ & $\mathrm{f}(\mathrm{xn})$ \\
\hline 1 & -1 & 0 & -0.5 & 0.1439 \\
\hline 2 & -1 & -0.5 & -0.75 & -0.0027 \\
\hline 3 & -0.75 & -0.5 & -0.625 & 0.0682 \\
\hline 4 & -0.75 & -0.625 & -0.6875 & 0.0321 \\
\hline 5 & -0.75 & -0.6875 & -0.71875 & 0.0145 \\
\hline 6 & -0.75 & -0.71875 & -0.734375 & -0.3847 \\
\hline 7 & -0.734375 & -0.71875 & -0.7265625 & \\
\hline
\end{tabular}

Value $\lambda=-0.7265625$ is an approximate solution of the starting equation. Then, based on the formula (1), we calculate the remaining measures of all the subsets of the set $\mathrm{X}$.

The results are presented below:

$$
\begin{aligned}
& \mu\{\mathrm{a}\}=0.2037 \\
& \mu\{\mathrm{a}, \mathrm{b}\}=0.518343 \\
& \mu\{\mathrm{a}, \mathrm{b}, \mathrm{c}\}=0.910394 \\
& \mu\{\mathrm{a}, \mathrm{b}, \mathrm{c}, \mathrm{d}\}=1.01016 \\
& \mu\{\mathrm{a}, \mathrm{b}, \mathrm{d}\}=0.702057 \\
& \mu\{\mathrm{a}, \mathrm{c}\}=0.739522 \\
& \mu\{\mathrm{a}, \mathrm{c}, \mathrm{d}\}=0.875877 \\
& \mu\{\mathrm{a}, \mathrm{d}\}=0.454784 \\
& \mu\{\mathrm{b}\}=0.3693 \\
& \mu\{\mathrm{b}, \mathrm{c}\}=0.829454 \\
& \mu\{\mathrm{b}, \mathrm{c}, \mathrm{d}\}=0.946553 \\
& \mu\{\mathrm{b}, \mathrm{d}\}=0.584926 \\
& \mu\{\mathrm{c}\}=0.6289 \\
& \mu\{\mathrm{c}, \mathrm{d}\}=0.788941 \\
& \mu\{\mathrm{d}\}=0.2947
\end{aligned}
$$

Based on the formula (4) we can calculate Shapley values for all four variables:

$$
\begin{aligned}
& \varphi_{a}(\mu, X)=0,07463, \varphi_{b}(\mu, X)=0,14866 \\
& \varphi_{c}(\mu, X)=0,29911, \varphi_{d}(\mu, X)=0,1136 .
\end{aligned}
$$

The third variable has the greatest Shapley value

\section{CONCLUSION}

Intellectual capital is the main value driver within a company, with a combined use of its three components: human capital, structural capital and organizational capital. The intellectual capital leads to positive results only with synchronized use of these three main components.

The purpose of our research was to examine the levels importance of each intellectual capital component. The importance of each intellectual capital component presents its contribution in the final performance of company. The intellectual capital literature is organized around three types of components: human capital, structural capital and relational capital. Each component has its particu- 
lar different importance for every company. Our paper is focused on the last two intellectual capital components, structural and relational.

The paper was based on two quantitative methods that relied on the analysis of financial information of companies: Lambda Phase Measurement Method and Shapley's Value Method. Our paper diverges from the existing literature by conducting a quanti-statistical analysis of disclosure practices, based on a sample of French companies, without any previous selection by sector. The results of empirical analysis of 498 French companies were used to fill the gap in the literature about the estimation of intellectual capital components importance.

Our results may have important implications to companies' decision- making processes. While the current managements seek to improve its financial performance with a high level of risks and uncertainty, the findings from this paper suggest that investments in a particular component can even enhance higher company's financial performance by reducing risks in the managerial investment decisions. This research suggests that managers should pay more attention to the Relational component of intellectual capital. The role of the particular intellectual capital component necessitates a more intensive use in the future value creation processes.

\section{REFERENCES}

1. Bassi, L. J. 1997. "Harnessing the Power of Intellectual Capital." Training \& Development 51 (12): 25-30.

2. Bayburina, E., and Golovko, T. 2009. "Design of Sustainable Development: Intellectual Value of Large BRIC Companies and Factors of Their Growth." Electronic Journal of Knowledge Management 7 (5): 535-58.

3. Bontis, N. 1996. "There's a Price on Your Head: Managing Intellectual Capital Strategically." Ivey Business Journal (Formerly Business Quaterly), 40-47.

4. Bontis, N. 1998. "Intellectual Capital: An Exploratory Study That Develops Measures and Models." Management Design 36 (2): 63-76.

5. Bontis, N., William C.C.K., and Richardson, S. 2000. "Intellectual Capital and Business Performance in Malaysian Industries." Journal of Intellectual Capital 1 (1): 85-100. https://doi.org/10.1108/14691930010324188.

6. Bukh, P.N., Larsen, H.T., and Mouritsen, J. 2001. "Constructing Intellectual Capital Statements." Scandinavian Journal of Management, 87-108.

7. Cascio, W.F. 1998. "The Future World of Work: Implications for Human Resource Costing and Accounting." Journal of Human Resource Costing \& Accounting 3 (2): 9-19.

8. Chatzkel, J. L. 2002. Intellectual Capital. Oxford: Capstone Pub.

9. Cherubini, U. 1997. "Fuzzy Measures and Asset Prices:
Accounting for Information Ambiguity." Applied Mathematical Finance 4 (3): 135-149.

10. Chen, J., Zhaohui, Z., and Hong Y. X. 2004. "Measuring Intellectual Capital: A New Model and Empirical Study." Journal of Intellectual Capital 5 (1): 195-212. https://doi. org/10.1108/14691930410513003.

11. Chen, M.C., Cheng, S.J., and Hwang, Y. 2005. "An Empirical Investigation of the Relationship between Intellectual Capital and Firms' Market Value and Financial Performance." Edited by Nick Bontis. Journal of Intellectual Capital 6 (2): 159-76. https://doi. org/10.1108/14691930510592771.

12. Edvinsson, L., and Stenfelt, C. 1999. "Intellectual Capital of Nations for Future Wealth Creation." Journal of Human Resource Costing \& Accounting 4 (1): 21-33.

13. Edvinsson, L., and Sullivan, P. 1996. "Developing a Model for Managing Intellectual Capital." European Management Journal 14 (4): 356-64. https://doi. org/10.1016/0263-2373(96)00022-9.

14. El-Bannany, M. 2008. "A Study of Determinants of Intellectual Capital Performance in Banks: The UK Case." Journal of Intellectual Capital 9 (3): 487-98. https://doi. org/10.1108/14691930810892045.

15. Garanina, T., and Pavlova, J. 2011. "Intangible Assets and Value Creation of a Company: Russian and UK Evidence." In , 165-75. Nicosia, Cyprus.

16. Gogan, M. L., and Draghici, A. 2013. "A POSSIBLE APPROACH FOR GENERIC MODEL CONCERNING INTELLECTUAL CAPITAL EVALUATION." ANNALS OF THE ORADEA UNIVERSITY. Fascicle of Management and Technological Engineering. XXII (XII), 2013/1 (1). https://doi.org/10.15660/AUOFMTE.2013-1.2788.

17. Hermans, R., and Kauranen, I. 2005. "Value Creation Potential of Intellectual Capital in Biotechnology - Empirical Evidence from Finland." $R$ and $D$ Management 35 (2): 171-85. https://doi.org/10.1111/ j.1467-9310.2005.00381.x.

18. Hudson, W. J. 1993. Intellectual Capital: How to Build It, Enhance It, Use It. New York: J. Wiley.

19. Itami, H., and Roehl, T.W. 2009. Mobilizing Invisible Assets. Cambridge: Harvard University Press.

20. Kin, G., and Saleh, Z. 2008. "Intellectual Capital and Corporate Performance of Technology-Intensive Companies: Malaysia Evidence." Asian Journal of Business and Accounting 1: 113-30.

21. Llano, C. 2002. Falacias y Ámbitos de La Creatividad. Editorial Limusa. Mexico: Noriega Editores.

22. Marr, B., and Moustaghfir, K. 2005. "Defining Intellectual Capital: A Three-dimensional Approach." Management Decision 43 (9): 1114-28. https://doi. org/10.1108/00251740510626227.

23. Martínez-Torres, M.R. 2006. "A Procedure to Design a Structural and Measurement Model of Intellectual Capi- 
tal: An Exploratory Study." Information \& Management 43 (5): 617-26. https://doi.org/10.1016/j.im.2006.03.002.

24. Ognjanović, J. 2017. "Relations of Intellectual Capital Components in Hotel Companies.” Industrija 45 (2): 181-96. https://doi.org/10.5937/industrija45-12144.

25. Ordóñez de Pablos, P. 2003. "Intellectual Capital Reporting in Spain: A Comparative View." Journal of Intellectual Capital 4 (1): 61-81. https://doi. org/10.1108/14691930310455397.

26. Pap, E., and Blagojević, A. 2019. "Primena Lambda Fazi Mere i Šeplijeve Vrednosti Na Procene Performansi Robe u Skladištima.” In . Univerzitet Singidunum Beograd.

27. Pike, S., Rylander, A., and Roos, G. 2002. "Intellectual Capital Management and Disclosure." The Strategic Management of Intellectual Capital and Organizational Knowledge, Oxford University Press, New York, 657-71.

28. Pulic, A. 1998. "Measuring the Performance of Intellectual Potential in Knowledge Economy.” In .

29. Roos, G., and Roos, J. 1997. "Measuring Your Company's Intellectual Performance.” Long Range Planning 30 (3): 413-26. https://doi.org/10.1016/S0024-6301(97)90260-0.

30. Saintonge, H. 1999. "Tacit Knowledge: The Key to the Strategic Alignment of Intellectual Capital.” In Knowledge and Strategy, 223-30. Elsevier. https://doi.org/10.1016/ B978-0-7506-7088-3.50015-2.

31. Stewart, T. 1991. "BRAINPOWER Intellectual Capital Is Becoming Corporate America's Most Valuable Asset and Can Be Its Sharpest Competitive Weapon. The Challenge Is to Find What You Have -- and Use It." Fortune Magazine, 1991. http://archive.fortune.com/magazines/ fortune/fortune_archive/1991/06/03/75096/index.htm.

32. Stewart, T.1995. "Trying to Grasp the Intangible." Fortune Magazine, October 2, 1995.

33. Stewart, T. 2001. "Accounting Gets Radical." Fortune Magazine, April 16, 2001.

34. Subramaniam, M., and Youndt, M.A. 2005. “The Influence of Intellectual Capital on the Types of Innovative Capabilities." Academy of Management Journal 48 (3): 450-63. https://doi.org/10.5465/amj.2005.17407911.

35. Sugeno, M. 1974. “Theory of Fuzzy Integrals and Its Applications." Tokyo, Japan: Tokyo University of Technology.

36. Sveiby, K. E. 1997. The New Organizational Wealth: Managing \& Measuring Knowledge-Based Assets. 1st ed. San Francisco: Berrett-Koehler Publishers.

37. Youndt, M.A., Mohan, S., and Scott A.S. 2004. "Intellectual Capital Profiles: An Examination of Investments and Returns*: Intellectual Capital Profiles." Journal of Management Studies 41 (2): 335-61. https://doi.org/10.1111/ j.1467-6486.2004.00435.x. 